\title{
Veidenbauma dzejas intertekstualitāte
}

\author{
Juris Kastiņš
}

Raksts veltīts Eduarda Veidenbauma lirikas analīzei intertekstualitātes teorijas aspektā, tā tuvinot latviešu dzejas problēmu risinājumu modernajām Rietumeiropas un ASV literatūras skolām 20. gadsimta otrajā pusē un 21. gadsimta pirmajā desmitgadē.

Teorētiskais pamatojums teksta izpratnei sniegts, izmantojot Mihaila Bahtina un Jūlijas Kristevas koncepcijas un papildinot tās ar pazīstamākajām vācu (Olivers Šeidings, Ulrihs Broihs, Manfrēds Pfisters, Zuzanna Holthuiza), franču (Žerārs Ženets, Rolāns Barts), amerikāṇu (Mihaēls Rifatērs) un citu zinātnieku tēzēm par intertekstualitāti, kultūras atmiṇu (mnemoniskā kultūras konstrukcija u. tml.), palimpsestu un citiem minētās teorijas terminiem.

Analizējot Eduarda Veidenbauma dzejol̦us, par pamatu izvēloties tekstu "Kā gulbji balti padebeši iet", uzskatāmi tiek apliecināts tā palimpsesta raksturs un hipertekstualitāte. Kultūratmiņas koncepcijas aspektā teksts klasificējams kā romantisma laikmeta intertekstualitātes palimpsests. Analīzē minētas daudzas Eduarda Veidenbauma dzejas alūzijas arī citos tekstos, kas saistīti ar viṇa laikmeta literārajiem strāvojumiem (naturālisms un citi).

Raksts ir viens no pirmajiem mēgeinājumiem izvērtēt latviešu literatūras klasiḳu darbus atbilstoši 20. gadsimta otrās puses un 21. gadsimta sākuma perioda principiāli jaunajām literatūrteorētiskajām nostādnēm, pie kurām neapšaubāmi pieskaitāma intertekstualitāte kā novatoriska Rietumu pasaules literatūras teorija.

Raksturvārdi: intertekstualitāte, palimpsests, autora refleksivitāte, alūzija, recipients.

Vai jums ir gadījies, kādreiz pastaigājoties mežā, piepeši atrast avotinu, kas, mutuḷojot un smiltis lēni griežot, izplūst starp zaḷām un sirmām sūnām? Visapkārt milzīgas priedes, bērzi un ozoli, bet saules stars tomēr paretam iezib arī avotā, tad, liekas, tur kaut kas atspīd un vizuḷo, it kā tas būtu kāds sens raksts ar dīvainām zīmēm, tad izdziest, lai atkal varētu parādīties cits teksts, - vārds nomaina vārdu, rinda veidojas aiz rindas, bet jums šķiet, ka skatāties audumā, kas sastāv no tūkstošiem dzīparu, kuri visi kopā veido jaunu un vēl nelasītu tekstu. Nacionālās dzejas pirmavots, latviešu lirikas pirmsākumi, latviešu literatūras vārdi, kas izdzīvo savu mūžu, uzkrājuši daudzās kultūrās un literatūrās iegūtas nozīmes. Vārds runā ar sevi un visām savām nozīmēm, bet vārds runā arī ar citu vārdu, kḷūstot par teksta audumu. Viens literārais teksts ieplūst citā literārajā vai arī neliterārajā tekstā, veidojot jaunas sakarības un nozīmes. Teksts nekad nav vientuḷš, 
tas vai nu slēpti, vai arī atklāti korelē ar citiem tekstiem pat tad, kad autors to neapzinās. Latīnu izcelsmes termina textus etimologijā jau ietverta tekstūras nozīme - teksts ir savijums no dažādiem heterogēniem materiāliem, no vārdiem, no kuriem, kā to atzinis Mihails Bahtins, gan pirmām kārtām ar to domājot romāna vārdu, piemīt dialoga daba - to sauc arī par dialoǵitāti -, viens vārds ar visām savām vēsturiskā ceḷā iegūtām nozīmēm "sarunājas" ar citiem vārdiem, tāpat kā viens teksts nepārtraukti ir dialog̣iskās attiecībās ar citiem tekstiem, kā to atzīst Jūlija Kristeva, pārnesot Mihaila Bahtina ideju no vārda uz intertekstualitāti.

"Teksts ir bezgalīga tekstu attiecību spēle, tāpēc intertekstualitāte ir atvērts process, kas atklāj nebeidzamu teksta jēgas padziḷināšanu," raksta Olivers Šeidings darbā "Intertekstualitāte". ${ }^{1}$ Zilas debesis ar baltiem padebešiem atspīd avotā, un šā romantiskā prototeksta dialogs ar tam līdzīgiem prototekstiem raisa tipisku konteksta attiecību spēli: ilgas pēc dienvidiem, nevīstošām rozēm, "laimības" ir vārdu un tekstu kodu "sasaukšanās" rezultāts - vārds atpazīst vārdu, teksts atpazīst kontekstu, un intertekstualitāte funkcionē. Kādā veidā, kā tas notiek, tas jau ir literatūrzinātnes pētniecības darbs - vai tā ir retorika, hermeneitika, strukturālisms, visbeidzot, lasītāja recepcija, kas atpazīst un dekodē intertekstualitātes izraisīto enerǵiju, - tas viss ir tālākās analīzes darbs. Eduarda Veidenbauma teksts saslēdzas ar veselu kultūrtekstu tīklu (teiksim, vācu romantismu) un iegūst savu kultūrvēsturisko orientāciju. Notiek "mnemoniska kultūras konstrukcija", kā to apzīmē Olivers Šeidings. ${ }^{2}$ Iespējams, ka tieši tādēḷ mums liekas, ka avotā piepeši pazib vēl citi dzēsti vai izdzisuši teksti - Eduarda Veidenbauma rindas ir uzrakstītas uz kāda senāka manuskripta, to saucam par palimpsestu, atzīstot šā termina autora Žerāra Ženeta teoriju par otrās pakāpes literatūru. ${ }^{3}$

Eduarda Veidenbauma dzejolis "Kā gulbji balti padebeši iet" ir klasisks dzejas intertekstualitātes paraugs, jo apvieno sevī daudzas "individuālās un kolektīvās uztveres" īpatnības, kā apgalvo vācu zinātnieks Vilhelms Foskamps ${ }^{4}$ minētajā Olivera Šeidinga rakstā. Dzejolis turklāt ir izteiksmīgs Veidenbauma pašrefleksijas paraugs. Ievērojot Ženeta klasifikāciju, kurā viņš intertekstualitātes vietā lieto precīzāku apzīmējumu "transtekstualitāte", varam teikt, ka šis dzejolis ir tipiska hipertekstualitātes izpausme. Hipertekstualitāte nozīmē, ka tajā fiksēta korelācija starp kādu prototekstu (hipotekstu) un doto dzejnieka darbu (hipertekstu), kā arī nosakāmi dažādi tekstu transformācijas veidi. Ženets izšḳir rotaḷīgos, satīriskos un nopietnos hipertekstus ar tiem atbilstošiem izteiksmes līdzekḷiem (parodija, pastišs, travestija, izjokošana, transpozīcija, atdarinājums). Tomēr Ženeta klasifikācijai nebūtu jāseko burtiski, jo tad mēs drīz vien nonāktu pie nepareiziem secinājumiem. Dzejolis "Kā gulbji balti padebeši iet", protams, nav ne parodija, ne pastišs vai travestija, kaut gan Veidenbauma dzejā šīm stila figūrām ir

1 Scheiding, O. Intertextualität. In: Gedächtniskonzepte der Literaturwissenschaft. Hrsg. A. Erll, A. Nünning. Berlin, New York: Walter de Gruyter, 2005, S. 53.

2 Turpat, S. 55.

3 Šeit un turpmāk par šo teoriju: Genette, G. Palimpseste. Die Literatur auf zweiter Stufe. https://www.geisteswissenschaften.fu-berlin.de/v/littheo/methoden/intertextualitaet/ darstellungen/kopp_genette.pdf [sk. 04.06.2020.]

${ }^{4}$ Citēts pēc: Scheiding, O. Intertextualität, S. 55. 
liela intertekstuāla nozīme (baznīcas tekstu parodija vai travestija). Mūs interesē Ženeta doma par palimpsestu kā kultūras atmiṇas iemiesojumu, kā kāda literāra procesa apliecinājumu. Pie nopietnajiem hipertekstiem zinātnieks pieskaita tādus tekstus, kuros vērojama kāda hipoteksta stila vai tēmas transpozīcija, tas pilnībā atbilst vismaz pirmajām četrām rindām:

Kā gulbji balti padebeši iet, Tiem vēlētos es līdza tālu skriet, Tur tālumā, kur ziemas nepazīst, Kur rozes mūžam zied un nenovīst.

Atšķirībā no Ženeta, kuram literatūras laikmeti un stili nav pats svarīgākais apstāklis, lai atklātu slēptās intertekstualitātes sakarības, mēs tomēr pievērsīsim uzmanību spilgti izteiktajam romantiskās atribūtikas kompleksam, turklāt nepretendējot uz to, ka Veidenbauma dzejolis ir kāda hipoteksta palimpsests. Tas neapšaubāmi norāda uz vairākiem romantisma kompleksiem: debesis kā tipisks romantisma bezgalības simbols (tiekšanās uz nekad neaizsniedzamo tāli), mākoṇi kā mūžīgas mainības simbols un, visbeidzot, gulbji, kuru simbolika ir vēl sarežğìtāka, jo tās tradīcija konstatējama jau kopš antīkā laikmeta. Izteiksmīgi fiksēts tā sauktais romantisma dienvidu komplekss, kas tik bieži apspēlēts arī mūsdienu postmodernisma literatūrā.

Priekšstats par Dienvidu zemi ("pēc kaut kā cēla un nezināma sirds ilgojas"5), kur krāšņā daba sagaidīs skumjās un ilgās nogrimušo indivīdu, lai dotu tam laimīgu dzìvi, tik bieži atkārtojas romantiķu darbos, ka šeit nav vajadzīgs pat viens konkrēts teksts, lai to pierādītu.

Faktiski jau pirmsromantisma literatūrā izveidojas idealizēts priekšstats par Grieķiju un Itāliju kā "laimības zemēm”, kuras kādreiz sasniegt ir dzejnieka dzīves mērḳis. Šajā ziṇā tipisks piemērs ir Gētes proponētā Itālija, kas jau no bērnības bija viņa sapņu un ideālu zeme un noveda pie "bēgšanas" uz Dienvidu nevīstošo ziedu un mākslas (tai skaitā arī antīkā laikmeta nepārspēto paraugu) pasauli. Izcils šā dienvidu kompleksa paraugs, protams, ir Gētes "Cel,ojums uz Itāliju", vēlāk daudzu vācu romantiḳu iedvesmas avots. Domāju, ka Rolāna Barta pazīstamais citāts par intertekstu ir daudz precīzāks un ietilpīgāks par Jūlijas Kristevas lozungu, ka "katrs teksts ir veidots kā citātu mozaīka", kāda cita teksta absorbācija un transformācija. ${ }^{6}$ Barts savukārt uzsver interkulturālo aspektu, kad raksta par tekstu kā "citātu savijumu", papildinot teikto ar frāzi, ka citāti nāk no "tūkstošiem kultūras fokusu":

5 Tā gan nav Veidenbauma dzejas rinda, kaut tautas tradīcijā dziesmas "Es zinu, visi mani nievā .." vārdiem pieraksta Veidenbauma autorību. Veidenbauma rakstos šāda dzejoḷa nav, tomēr ir divi Treiman̦a-Zvārguḷa dzejoḷi, no kuriem radušies šīs dziesmas vārdi M. Rižija komentārs.

${ }^{6}$ Kristeva, J. Bachtin, das Wort, der Dialog und der Roman. In: Literaturwissenschaft und Linguistik. Ergebnisse und Perspektiven. Hrsg. W. Jens. Bd. 3: Zur linguistischen Basis der Literaturwissenschaft II. Frankfurt am Main: Athenäum-Verlag, 1972, S. 345-375. 
[..] teksts neveidojas no vārdu virknes, kurā atklātos viena, savā ziṇā teoloğiska (Autora - Dieva - vēstījuma) jēga, bet tas ir daudzdimensiju telpa, kurā vienojas un viena otru apstrīd dažādas rakstības, no kurām neviena nav oriğināla: teksts ir austs no citātiem, kuri nākuši no tūkstošiem kultūras fokusu. ${ }^{7}$

Neiedziḷinoties intertekstualitātes koncepcijās, atzīmēsim tikai to, kas šķiet vissvarīgākais mums, lai labāk izprastu Veidenbauma dzejoḷa kontekstuālo problemātiku. Šķiet, literatūrā nav viena teksta references, uz kuru tad varētu atsaukties kā neapšaubāmu palimpsestu, tāpēc te drīzāk ir runa par sistēmisku referenci, kas saistīta ar jau agrāk minēto intertekstualitātes kultūratmiņas orientāciju, kuru pašlaik Rietumu literatūrzinātne intensīvi apgūst dažādos aspektos. Līdztekus antîkās pasaules avotiem (intensīvas Horācija studijas un atdzejojumi) Veidenbaums tikpat radoši apgūst vācu romantismu, galvenokārt pievēeršoties klasiķiem ar sociāliem un arī anakreontiski iezīmētiem akcentiem, kas acīmredzot vinam lieti noder oriǵināldzejā. Raksturīgi, ka Jēnas agrīnais romantisms ar Vilhelmu Heinrihu Vakenroderu, Ludvigu Tīku un Novālisu, manuprāt, neiezīmējas dzejnieka palimpsestā. Veidenbaumam vispār ir neraksturīgi kavēties teiku un leǵendu vai latviešu dievību mitolog̣ijā un pasaulē, kas tik tipiski Auseklim, tāpat slavēt kristietību, kā to proponēja Novāliss. Latviešu folkloras zelta ābols neiekrīt Veidenbauma dzejas avotā, kaut gan pati ābele, škiet, zaro kaut kur pavisam tuvu dzidrajiem ūdens atspulgiem. Veidenbaums ievēro Horācija doto dzīves padomu:

Kur egle slaikā, baltajai papelei

Klāt zarus sniedzot, pakrēsli izplata,

No stāva krasta ātros viḷnos

Avota ūdens kur upē steidzas,

Tur vīnu nest liec, smaržīgas nardes ar’

Un sārtas rozes, pārāk kas ātri vīst,

Lìdz laiks vēl atḷauj, līdz vēl liktens

Griezis nav dzīvības diegu vājo. ${ }^{8}$

Veidenbauma intertekstualitāte nepastarpināti atklājas viṇa atdzejojumos. Anakreontiski dzīvespriecīgais un mirkli baudošais fons dzejniekam, tāpat kā romantiski skumjās ilgas pēc "laimības", vajadzīgs galvenokārt kontrastam: te ir tavas ilgas pēc tālās idealizētās zemes, bet šeit ir neizbēgamā atzinna par dzīves sociālo netaisnību un paša eksistences isslaicīgumu, par tuvo nāvi. Heinriha Heines, Frīdriha Šillera un Horācija atdzejojumi izvēelēti galvenokārt traọiska konflikta referencei oriǵināldzejā, tas ir īpašs intertekstualitātes "treniṇš", kurā Eduards Veidenbaums aprobē sev raksturīgo eksistences izpratni.

7 Barthes, R. Der Tod des Autors. In: Texte zur Theorie der Autorschaft. Hrsg. F. Jannidis, G. Lauer, M. Martinez, S. Winko. Stuttgart, 2000, S. 190. Šeit citēts pēc: Barts, R. Autora nāve. Tulk. A. Skrābane. Grāmata, 1992, V/VI, 21. lpp.

8 Veidenbaums, E. Kā gulbji balti padebeši... Rīga: Liesma, 1967, 153. lpp. 
Vācu zinātnieks Manfrēds Pfisters klasificē intertekstualitātes references, kas interesantas arī salīdzinājumā ar Eduarda Veidenbauma atdzejojumu un oriǵināldarbu attiecībām. Pirmā no tām ir pati referencialitāte, ar kuru autori saprot tematisko aspektu, tas ir, kāda sveša teksta atklāsmi dzejnieka darbos. ${ }^{9}$ Šeit saskare ir tieša un nepārprotama: steidzies baudīt dzīvi, bet arī cīnies par to! Frīdriha Šillera "Jātnieku dziesma" ir nepārprotams tematisks korelāts intertekstualitātei:

Nu taisāties, biedri, nu jāsim viss bars

Uz kauju, uz svabadu dzīvi!

Iz pasaules brīvība nīcin nīkst,

Tik kalpību ieraudzìt vari;

Pie kājām viltīgiem blēžiem slīgst

Tie gḹevie cilvēku bari.

Met skumjas reiz projām pie malas!

Tur kaujā pūš brīvības dvaša. ${ }^{10}$

Otrs kritērijs intertekstualitātei ir autora (un arī recepcijā - lasītāja) intertekstualitātes apzināšanās pakāpe, kura, domājams, Veidenbaumam ir visai augsta, - dzejnieks speciāli no plašā mantojuma vai kultūratmiṇas izvēlējies tos tekstus, kas "pasaka priekšā" viņa tematiku un problemātiku. Autora pašrefleksijas pakāpe attiecībā uz intertekstualitāti arī ir acīmredzama un neapšaubāma. To apliecina ne tikai tekstu selektivitāte, bet arī l̦oti radniecīgas rindas Veidenbauma veiktajos atdzejojumos un viņa oriǵināldzejā. Salīdzināsim tikai vienu citātu no Šillera "Uzvaras svētki" ar dzejoli "Jau ziedoṇa vēsmas no dienvidiem plūst":

Priekus baudīsim šodien!

Rìt varbūt jau dzìve beidzas. ${ }^{11}$

Un oriǵināldarbā:

Tad, kamēr vēl jaunība dzīslās mums rit,

Lai jautrībai neḷaujam beigties.

Kad miršanas tumšajā stunda reiz sit,

Uz mieru lai varam tad steigties! ${ }^{12}$

\footnotetext{
9 Pfister, M. Konzepte der Intertextualität. In: Intertextualität: Formen, Funktionen, anglistische Fallstudien. Hrsg. U. Broich, M. Pfister. Tübingen: Max Niemeyer Verlag, 1985, S. 26.

${ }^{10}$ Turpat, S. 131-132.

${ }^{11}$ Veidenbaums, E. Kā gulbji balti padebeši..., 139. lpp.

${ }^{12}$ Turpat, 91. lpp.
} 
Gribētos apgalvot, ka autora refleksivitāte ir tik spilgti izteikta visā Veidenbauma dzejā, bet recepcija profesionālu literatūrzinātnieku personā nonāk pie tā sauktā gaidu apvāršña (Erwartungshorizont), kas nozīmē, ka, lasot atdzejojumus, mēs jau perspektīvā varam iztēloties un sagaidīt referentatīvas rindas paša autora darbos. Palimpsests faktiski nav vajadzīgs, jo autora elastīgums kā radošs princips to padara lieku. Hipoteksts un hiperteksts atrodas tik ciešā saiknē viens ar otru, ka varam runāt par transformāciju vai vietām pat par atdarināšanu, kas tuvojas pastišam. Katrā ziṇā starp atdzejojumiem un orig̣ināldzeju vērojama neapšaubāma dialogitāte, kad gan semantiskie, gan arī ideoloǵiskie akcenti apliecina savstarpēju pievilkšanās un atpazī̌sanas pakāpi. Prototeksti - atdzejojumi - arī strukturāli iekḷaujas originināldarbos, integrējas tajos.

Visbeidzot, atdzejas tekstu izvēle kā īpašs selektivitātes princips norāda uz mērḳtiecīgu referencialitāti - Veidenbaums nav atdzejojis, piemēram, Novālisa garīgās dziesmas vai Jozefa Eihendorfa smalklirikas harmoniskos romantisma pantus. Vācu jaunromantisms un jūgendstils hronolog̣iski nevar iekḷauties Veidenbauma daiḷradē, jo to pirmsākumi datējami ar 19. gadsimta pēdējo desmitgadi, kad dzejnieka jau vairs nav. Ietekmi uz vina dzeju atstājis naturālisms, kura uzplaukums saistās tieši ar 80. gadiem. 1885. gadā Vācijā rakstnieks Vilhelms Ārents izdod naturālisma dzejnieku antologiju "Modernie dzejnieku raksturi" (Moderne Dichter-Charaktere), kas gan literatūras vēsturē iegājusi drīzāk ar negatīvu nekā pozitīvu vērtējumu, uzrādot jaunā sociāli kritiskā virziena poētiski deklaratīvo vājumu. ${ }^{13}$ Gadu vēlāk iznāk naturālisma teorijas un jaunās "dzejas revolūcijas" karognesēja Arno Holca krājums "Laika grāmata. Modernista dziesmas" (Buch der Zeit. Lieder eines Modernen) - acīmredzot labākais naturālistu sniegums lirikā. ${ }^{14}$ Nav zināms, vai Veidenbaums lasījis šos avotus, kas gan ir l,oti iespējams, jo sakrīt ar viṇa intensīvām studijām un vēlmi kāri tvert jaunākā literārā procesa norises. Turklāt daudzās gan nojaušamās, gan tieši fiksējamās alūzijas, kuru tik daudz vai katrā Veidenbauma dzejolī, netieši norāda uz radniecīgu intelektuālo atmosfēru. Piekrītot Kristevai, ka intertekstualitāte kā suverēna literatūras teorijas skola nekādā ziṇā nav literāro virzienu un dzejnieku ietekmes "inventūra", tomēr nevar ignorēt Veidenbauma "lirikas auduma rakstā" fiksētos "references signālus", kā tos dēvē Žans Starobinskis, lai parādītu slēptos, neklātesošos in absentia "attieksmes tekstus", kas atklājas kā "iniciālteksti", "preteksti" vai izcelsmes teksti. ${ }^{15}$ Faktiski "alūziju marḳieri” vai "alūziju indikatori", kā tos dēvē Zuzanna Holthuiza savā izcilajā monogrāfijā par intertekstualitāti, lasītājiem kā teksta receptoriem referentatīvi parādās dzejoḷa "Kā gulbji balti padebeši iet" jau piektajā un tai sekojošās rindās:

\footnotetext{
${ }^{13}$ Moderne Dichter-Charaktere. Hrsg. W. Arendt. Berlin: [o. V.]. 1885.

${ }^{14}$ Holz, A. Buch der Zeit. Lieder eines Modernen. Berlin: Verlag der Contumax GmbH\&Co. KG, 1886.

${ }^{15}$ Starobinski, J. Le texte dans le texte. In: Tel Quel, 1969, 37, p. 4-33. Zit. nach: Holthuis, S. Intertextualität. Aspekte einer rezeptionsorientierten Konzeption. Tübingen: Stauffenburg Verlag, 1993.
} 
Kam veltīgi laimību kāro tu, sirds?

Met projām reiz cerības tumšajā kapā:

No saulainām lejām ir mirstīgais šķirts,

Tam jādzìvo asaru dūksnājā slapjā [..].

Manifestētā teksta (Veidenbauma dzejas citāts) un attieksmes teksta (in absentia) genētiskā sakarība ir visai komplicēts process, kura pierādīšana nereti ir nepieciešama recipienta intelektuālā kompetence, kas uztver marḳierus kā signālus gan tēmas, gan motīvu kopsakarībā. Tā, piemēram, par cilvēka "nolādēto likteni" būt darba vergam šajā briesmīgajā pasaulē, kur jāatsakās no "laimības", refrenciāli tuvs ir Arno Holca dzejolis bez virsraksta Lass doch dein Schlagen, lass doch, mein Herz...:

Lass doch dein Schlagen, lass doch mein Herz,

Sieh, die Welt ist ein grausamer Scherz,

Überall gähnt es dich an: Verzichte! ${ }^{16}$

Poētiski un stilistiski tas tuvs vācu dzejnieka rindām par cilvēka sociālo netaisnību. Šeit vēlreiz jāatzīmē, ka intertekstualitāte kā jauna literatūras teorija būtiski atšķiras no vecās literāro ietekmju un avotu skolas, kas mums sen pazīstama. Intertekstualitāte nepieprasa pierādìt faktu, ka dzejnieks ir vai nav lasījis tā vai cita autora darbus (un tad ietekmējies no tiem), intertekstualitāte salīdzina divus tekstus, kaut arī tos šķirtu gadu tūkstoši un cita pasaules izpratne. Tāpēc jau tas arī ir palimpsests. Tā, piemēram, Veidenbaumam nebūt nav vajadzējis baznīcā noklausīties kādu sprediķi, lai tas kā prototeksts atbalsotos viṇa dzejā, vai arī lasīt pirms simt gadiem izdotu Bavārijas sprediḳu grāmatu. Intertekstualitātei ir svarīgi saskatīt šo prototekstu kā palimpsestu, kā slēptu, "nodzēstu" tekstu, kas redzams kontrastīvā salīdzinājumā kā literārās mnemotehnikas vai literatūras kā kultūratmiņas elements. Bieži vien palimpsests atklājas sabiedriskās dzīves intelektuālajā atmosfērā - miljoni, piemēram, 19. gadsimta beigās runāja un domāja tāpat kā Frīdrihs Nīče, kaut gan nebija lasījuši nevienu viņa darbu. Visspilgtākais piemērs te varētu būt filozofa populārā ideja par Dieva nāvi.

Bet atgriezīsimies pie mūsu autora darbiem: vēl citā dzejolī raksturīgas rindas, kas jo tuvas Veidenbauma domai par "saulainām lejām":

Ich kann ja die Seele nicht baden

In dem goldigen Sonnenschein. ${ }^{17}$

Tāpēc vēl pārsteidzošāka ir kāda cita alūzija, kurai ir pavisam atšḳirīga ǵgenētiskā izcelsme, bet kas tematiski piekḷaujas Veidenbauma romantizēti sapṇainajām ilgām pēc "laimības". Tas ir kāds Cīrihē 1801. gadā izdots reliğiska rakstura

\footnotetext{
${ }^{16}$ Holz, A. Buch der Zeit. Lieder eines Modernen, S. 271. "Nepuksti, sirds [nozīmē: nepuksti ilgās pēc "laimības"], nepuksti, mana sirds [veltīgi kārojot skaistu dzīvi], Redzi, šì pasaule ir briesmīga, Tā visur tev draud: Atsakies!" [Šeit un turpmāk tulkojums mans - J. K.]

17 Turpat, S. 266. "Es nevaru dvēseli gremdēt / Saules zeltainajos staros."
} 
krājums "Sprediḳi slimiem, nabagiem, grūtsirdīgiem un mierināmiem cilvēkiem" (Unterhaltungen in "Predigten für Kranke, Arme, Schwermütige und Trostbedürftige"), kuru autors ir mācītājs un pedagogs Johanness Brunners. ${ }^{18}$ Šì negaidītā alūzija ir intertekstuāla parafrāze ar savu sintaktisko struktūru, taču tematiski l,oti tuva Veidenbauma rindām. Tas vēl jo pārsteidzošāk tāpēc, ka dzejniekam ir ḷoti daudz pavisam citu veidu alūziju ar reliǵiska rakstura tekstiem, kuri ir vai nu slēptā attieksmes teksta parodijas, travestijas, vai arī pastiši. Te preteksts in absentia skan bez ironijas, lai gan pilnīgas pārliecības par to nav, jo, iespējams, rindas "Kam veltīgi laimību kāro tu, sirds" zināmā rakursā un konfrontācijā ar "spredikci” var tikt uztvertas kā l,oti dziḷi slēpta ironija ("nu redz, tie cienīgtēvi taču arī spredik,o "Met cerības projām reiz tumšajā kapā..., veltīgi tu ceri šeit gūt laimi un mieru...”). Spredik̦a teksts skan: "Ak, cilvēk, velti tu tiecies pēc miera, ja tu domā, ka tā tu varēsi pilnīgi atbrīvoties no sāpēm un rūpēm. Tu šeit nekur neatradīsi pilnību, ne cilvēkos, ne apstākḷos. Visur, kur tu lūkojies, ir tikai grūtības un rūpesti." ${ }^{19}$ Veidenbauma dzejā vispār daudz alūziju ar religiskiem motīviem, brīžiem tie stilistiski pārvēršas līdz nepazišanai un kḷūst par pastiša vai parodijas viegli izmantojamu materiālu, iegūstot semantiski pretēju nozīmi, piemēram, "Tik pacieties, debesīs labāki būs!", kas gan ir it kā citēts "cienīgtēva" spredikis, tomēr vērtējams kā satīriska hipoteksta variants (līdzīgi travestijai, kad par augstām lietām (apsolītā paradīze pēc nāves) tiek runāts ar izsmieklu). ${ }^{20}$ Franču-amerikāṇu literatūrzinātnieks Mišels Rifatērs, vērtējot šādu literatūrsemiotikas gadījumu intertekstualitātes kontekstā, šo transformāciju sauc par "nozīmes pārvēršanu (līdz nepazǐšanai)", lietojot oriğinālterminu distorting meaning, ar to saprotot paradoksu, nonsensu u. tml. ${ }^{21}$ Tādu stilistisku figūru Veidenbauma dzejā ir daudz, taču nereti šādu alūziju saknes ir dziḷi paslēptas un tik viegli nav atrodamas. Turklāt attieksmes teksts kā oriǵināls var būt paslēpts no manifestētā teksta arī ar intertekstuālās parafrāzes palīdzību. Recipients sākumā var tikai nojaust, ka aiz kāda satīriska hiperteksta acīmredzot slēpjas persiflāža (Persiflage, ar ko saprot asprātīgu, izsmejošu un arī kritisku kāda darba atdarinājumu), tomēr, tās izcelsmi un transformāciju meklējot, tēlaini izsakoties, jāizdara kultūrarheoloğiski izrakumi. Satīriski kritizējot "mūsu dzīves nozīmi” kā "tīrās muḷ,ịības", dzejolī "Es domāju, ka pasaulē" lasām pazīstamās rindas:

Jo vēders - dievs visaugstākais,

Un katrs pats sev tuvākais,

Tiklīdz kā izsalcis.

\footnotetext{
${ }^{18}$ Brunner, J. Unterhaltungen in "Predigten für Kranke, Arme, Schwermütige und Trostbedürftige". Band 1. Zürich, 1801.

${ }^{19}$ Turpat, S. 368. Oriǵinālā: Vergeblich strebst du nach Ruhe, o Mensch, wenn du diesselbe nur suchest in einer gänzlichen Befreiung von Leiden und Kummer. Du wirst hiernieder nirgends Vollkommenheit finden, weder an Menschen, noch in den Umständen.

${ }^{20}$ Veidenbaums, E. Kā gulbji balti padebeši..., 21. lpp.

${ }^{21}$ Berndt, F.; Tonger-Erk, L. Intertextualiät. Eine Einführung. Berlin: Erich Schmidt Verlag, 2013, S. 101.
} 
Var tikai nojaust, kāda, iespējams, grēku nožēlas sprediḳa alūziju. ${ }^{22}$ Protams, šeit atkal ir semantikas paradoksāla karikēěšana distorting meaning veidolā.

Un, lūk, arī viens no iespējamiem attieksmes tekstiem, pirmteksts vai preteksts, kuru droši vien Veidenbaums nekad nav lasījis, bet kura radīto "intelektuālo atmosfēru" viegli varējis atpazīt reiz dzirdēta sprediḳa priekšlasījumā vai reprodukcijā. Kādas Bavārijas provinces Mazo brāḷu kapucīṇu ordeṇa "Dziesmu grāmatas vai Simt svētdienu un svētku dienu grēku nožēlas sprediķu" (1734) izdevumā lasām:
Vēders ir tavs Dievs, izslāpusī mēle - tava baznīca, blıdo un šķīvis - tavs altārs, pavārs - tavs priesteris, cepeša smarža - tava svētība. ${ }^{23}$

Šo un Veidenbauma tekstu vieno arī Bībele, kurā tekstā Vēstulē filipiešiem 3:19 teikts: "Viṇu Dievs ir vēders, un kauns viṇiem ir gods; viṇu prāts vērsts uz zemes lietām."

Domājams, tas ir spilgts palimpsesta gadījums, kad aiz Veidenbauma rindām slēpjas vēl daudzu agrāk rakstītu pretekstu ēnas. Dzejnieka lirika ir l,oti bagāta alūziju un citu intertekstualitātes stila figūru krātuve.

Bet vai gan citādi varētu būt? Latviešu nacionālās dzejas avots plūst pa brīnišku meža ainavu, kur visapkārt tik daudz noslēpumaina un skaista... Mūsu lirikā nav neviena teksta, kas nebūtu iespaidojies no krāšņās apkārtējās dabas un kultūras pasaules. Barts reiz izteicās, ka, piedzimstot dzejniekam, viṇš vienmēr ienāk kāda konteksta pasaulē, tāpēc katrs viņa teksts ir kā audums, kas sastāv no "citātiem no atškirīgām kultūras vietām... Teksts ir sastādīts no dažādiem rakstiem, kas radušies atškirīgās kultūrās un sarunājas cits ar citu, parodē cits citu, apšauba cits citu." ${ }^{24}$ Veidenbauma dzejas auduma raksti pilnībā apstiprina šo dziḷo Barta domu. Kultūras apziņa un kultūras atmiņa caurstrāvo visu Veidenbauma liriku.

Laikmeta konteksts neapšaubāmi ieaudis Veidenbauma tekstos savus rakstus. 19. gadsimta 80. un 90. gadu sākums ir arī naturālisma kā spēcīga strāvojuma periods.

Intertekstuāls salīdzinājums, piemēram, ar toreizējo vācu naturālisma liriku apliecina Veidenbauma fascinējošo reakciju uz sociālās īstenības atspoguḷojumu. Tādas ir dzejoḷa "Kā gulbji balti padebeši iet" četras noslēdzošās rindas:

\footnotetext{
${ }^{22}$ Veidenbaums, E. Kā gulbji balti padebeši..., 35. lpp.

${ }^{23}$ Burghusiano, C. Seraphisch-Buß- und Lobanstimmender Wald-Lerchleins. Zehnter Jahrgang. Hundert Sonn- und Feyer-Tags Predigten. Jg. 2 (1). Am zwanzigsten Sonntag nach Pfingsten. Capuciner-Orden der Bayrischen Provinz: 1734, S. 344.

${ }^{24}$ Barthes, R. Der Tod des Autors, S. 190.
} 
Kur dzelži un cirvji bez rimšanas klaudz, Pēc maizes, pēc pārtikas vergi kur sauc, No stiprākā samīts, vājāks kur lūst

Un asins un sviedri ik dienas kur plūst. ${ }^{25}$

Naturālisma lirikas antoloǵijā ir daudz dzejoḷu, kurus lasot atmiņā neviḷus ataust Veidenbauma rindas par sociālo netaisnību 19. gadsimta beigās. Karla Henkela darbā "Strādnieka dziesma" (Das Lied vom Arbeiter) atainotā smaga darba aina l,oti radniecīga Eduarda Veidenbauma rindām:

Es stammt und dröhnt mit dumpfem Ton

Und qualmt und raucht ringsum,

Und Mann an Mann in schwerer Fron

An seinem Platze stumm.

Der Hammer sinkt, die Esse sprüht,

Das Eisen in der Flamme glüht. ${ }^{26}$

Alūziju tipoloǵija šeit nepārprotama. Iespējams, tas ir gadijjums, kuru apraksta Umberto Eko, kad vērojamas līdzīgas intertekstuālas struktūras, kuras izpaužas, "reducējot dažādus priekšmetu [attēlojumus] uz vienu un to pašu homogēno atveidojuma iespēju". ${ }^{27}$ Teksti sasaucas viens ar otru vai, kā saka, savstarpēji referē. To sauc par heterointertekstuālām relācijām starp dažādu autoru tekstiem atškirībā no autointertekstuālām relācijām, kad intertekstualitāte izpaužas starp viena autora (Veidenbauma) dažādiem tekstiem. ${ }^{28}$ Veidenbauma lirika ir intertekstuāli l,oti bagāta ar dažādām apzinātām vai neapzinātām pretekstu relācijām, no kurām ilustrācijām varējām izmantot tikai dažas visraksturīgākās rindas. Dzejnieka lirikas kodi gaida savu 21. gadsimta recipientu, lai visā tās bagātībā atklātu tekstus kā bezgalīgas un vienmēr semantiski jaunas nozìmes.

\section{Intertextuality of Veidenbaums's poetry}

\section{Juris Kastiṇš}

The article is focused on the analysis of Eduards Veidenbaums's lyrics from the venture point of the theory of intertextuality, thus bridging Latvian poetry with modern schools of Western European and American literature in the second half of the $20^{\text {th }}$ century and the first decade of the $21^{\text {st }}$ century.

\footnotetext{
${ }^{25}$ Veidenbaums, E. Kā gulbji balti padebeši..., 9. lpp.

${ }^{26}$ Lyrik des Naturalismus. Hrsg. J. Schutte. Stuttgart: Philipp Reclam jun. Verlag, 1982, S. 117. "Viss dobji dun un rēc, / Visapkārt dūmi kūp un ceḷas, / Un vīrs pie vīra smagā darbā / Stāv savā vietā kluss, / Krīt āmurs, dzirksteles met skurstenis, / Dzelzs liesmā kaist."

${ }^{27}$ Eco, U. Einführung in die Semiotik. München: dtv, 1972, S. 361.

${ }^{28}$ Turpat, S. 45.
} 
Scholars have based the theoretical considerations on intertextuality, cultural memory (mnemonic cultural construction, etc.), palimpsest and other concepts developed by Mikhail Bakhtin and Julia Kristeva, as well as outstanding German (Oliver Scheiding, Ulrich Broich, Manfred Pfister, Susanne Holthuis), French (Gerard Genette, Roland Barthes), and American (Michael Riffaterre) scholars.

The analysis of Eduards Veidenbaums's poems, specifically the text White clouds are passing like swans (Kā gulbji balti padebeši iet), clearly demonstrates its palimpsest character and hypertextuality. In terms of the concept of cultural memory, the text can be classified as a palimpsest of Romantic era. The analysis contains many allusions to Eduards Veidenbaums's poetry in other texts related to the literary trends of his time (naturalism and others).

The article is one of the first attempts to evaluate the works of Latvian literary classics in accordance with the fundamentally new literary theoretical assumptions of the second half of the $20^{\text {th }}$ century and the beginning of the $21^{\text {st }}$ century, which undoubtedly include intertextuality as a state-of-the-art theory of Western literature.

Keywords: intertextuality, palimpsest, author's reflexivity, allusion, recipient. 